\title{
Skin Nodule
}

National Cancer Institute

\section{Source}

National Cancer Institute. Skin Nodule. NCI Thesaurus. Code C3373.

A benign or malignant round or oval and elevated solid lesion that arises from the skin or subcutaneous tissue. 